\title{
In Memoriam: A Tribute to \\ Dorothy A. Schwieder, 1933-2014
}

\author{
TOM MORAIN
}

IOWA HISTORY lost a great champion on August 13, 2014, when Dorothy Schwieder died at her home in Ames. For three decades, she reigned as the dean of Iowa historians. She taught Iowa history to thousands of students at Iowa State University, served multiple terms on the State Historical Society of Iowa (SHSI) Board of Trustees, gave of her time freely to community history projects and research requests, and authored an avalanche of books and articles on the state's history. Besides writing dozens of book chapters, scholarly articles, and encyclopedia entries, she authored, coauthored, or coedited nine books, including a monograph on Iowa's Old Order Amish, an elementary and middleschool Iowa history text, a popular Iowa history book, and the sesquicentennial history of Iowa State University. Because she was on the SHSI board at the time, her one-volume survey, Iowa: The Middle Land, was ineligible for consideration for the Benjamin F. Shambaugh Award, but because of its obvious significance, Governor Terry Branstad issued Dorothy a special citation for its contribution to the field. In 2008 SHSI presented her with its Petersen-Harlan Award for significant lifetime contributions to Iowa history, and in 2012 she was inducted into the Iowa Women's Hall of Fame.

Dorothy was my office mate, my mentor, my colleague, my coauthor, my favorite editor, my bridge partner, and my friend. She was also my job creator. After only a few years, Dorothy's Iowa history course at Iowa State had become so popular that she could no longer teach all the students who wanted to take it, even 
when each section was expanded to 100 students and even when it was taught on Tuesday, Thursday, and Saturday. I was hired to teach the overload - another 200 students, and the rest, so they say, is history.

When I was assigned a desk in Dorothy's office, she became the only regular history faculty member who had to share her office space. I feared that she would resent my presence, both in the office and as a trespasser on her Iowa history turf. I was wrong on both counts. She could not have been more gracious. She shared her syllabus, her reading list, and the best books to read as background sources. When I asked questions, she answered them and gave suggestions for my sections. I was surprised by how nice she was to me, but as the year went on, I found that she treated everyone the same way, students and fellow faculty members alike. She was a model of graciousness.

That gracious spirit extended to her family, her friends, her church, and her community, but it was in her role as Dorothy the Historian that I came to see it most clearly. She was equally at home in the classroom, in a small-town library or church basement, at a history conference or a SHSI board meeting. She took Iowa history to people all around the state. We all touched base with Dorothy when we wanted to start a research project. We wanted to get her suggestions or her recommendations for source material. If the truth were known, however, what we really wanted was her blessing - her affirmation, her approval - which, of course, she so readily provided. There is today a camaraderie among Iowa historians. We are a collegial crew, not competitive or turf guarding, and willing to help each other. It is Dorothy who set that tone and modeled a spirit of cooperative generosity.

And in a truly Dorothy-like way, that generosity extended to the people she wrote about in her books and articles. Her heart was with those whom more conventional historians ignored, those whose stories rarely made it into history books. In a way, her books, articles, and history talks paralleled and complemented the civil rights movement that was under way during the decades of her professional career. She brought to life people society - and most historians - were all too comfortable overlooking. She wrote about the wives of coal miners who worked long 


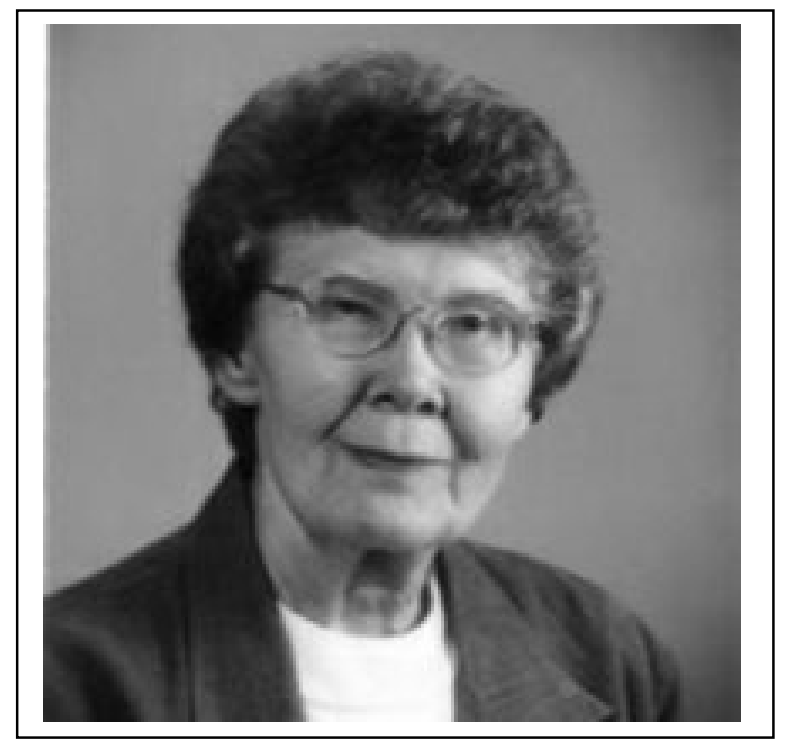

hours washing, ironing, and cooking not only for their own families but for relatives and for boarders. She and Elmer were invited into the homes and even to the dinner tables of the Amish who trusted them to tell their stories to a skeptical world. She wrote about Iowa farm wives on the frontier and in the Great Depression a century later who struggled through good times and bad to earn a better life for their children.

One of her favorite anecdotes was about an experience interviewing a coal miner's wife in the family's home. Under Dorothy's kindness, the woman opened up and talked freely about the hardships and hard work she had endured. During the interview, the woman's husband came in and sat in the corner of the room. When the phone rang, he didn't get up to answer it. It became obvious to Dorothy that in this family, it was the wife's job to jump up to get the phone whenever it rang. After repeated rings, the wife turned to her husband and told him sharply, "You get it. Dorothy is talking to ME." Here was a woman who must have felt so often invisible, who was rarely if ever asked her opinion about anything. She relished this hour-long opportunity to share her story with someone who considered that story important. Dorothy carried with her that respect for the worth of all persons not only into the interview and the research but into her 
writing as well. She found dignity in lives that others overlooked and treated them with integrity and her characteristic grace.

From the movie Field of Dreams comes the now famous tribute to the Hawkeye State - "Is this heaven? No, it's Iowa." When Dorothy comes to the Pearly Gates, she may wonder where she is and ask Saint Peter, "Am I still in Iowa?" He will respond, "No, this is heaven." And Dorothy will say, "Then let me tell you about Iowa." When she does, I hope he listens because no one knows Iowa better. Her legacy is not only in her writings, but in the spirit in which she engaged with her fellow Iowans - past and present-and her model of gracious generosity to all. We shall miss her. 